\title{
Mikroalg yağının lipaz katalizli hidroliz tepkimesine etki eden proses parametrelerinin istatistiksel yöntemle optimizasyonu
}

\author{
Statistical optimization of hydrolysis reaction process parameters by lipase catalysis of \\ microalgae oil
}

Togayhan KUTLUK*

Kocaeli Üniversitesi, Mühendislik Fakültesi, Kimya Mühendisliği Bölümü, 41380, Kocaeli

• Geliş tarihi / Received: 06.04.2020 • Düzeltilerek geliş tarihi / Received in revised form: 21.11.2020 • Kabul tarihi / Accepted: 26.11 .2020

\section{$\ddot{O ̈ z}$}

Birçok endüstriyel tesisin hammadde kaynağı olarak kullanılan yağların hidrolizi önemli bir kimyasal prosestir. Yağ asitleri yenilenebilir kaynaklardan üretilen yağların hidrolizi ile sentezlenir. Son yıllarda bitkisel ve hayvansal yağlara alternatif mikroalglerden elde edilen yağların hammadde kaynağı olarak kullanılması giderek yaygınlaşmaktadır. $\mathrm{Bu}$ çalışmada Design Expert bilgisayar programı yardımı ile Chlorella protothecoides mikroalg yağının Noopazyme lipazı katalizörlüğünde hidroliz tepkimesine etki eden parametrelerin (lipaz miktarı, sıcaklık, yağ/su (g/g)) etkileri incelenerek yüksek dönüşümle serbest yağ asitleri (SYA) elde etmek amacı ile optimizasyonu yapılmıştır. Deneysel çalışmalar sonucunda en yüksek SYA içeriği (\%98), lipaz miktarı $\% 15$, yağ/su oranı $(\mathrm{g} / \mathrm{g}) 0.20$ ve sıcaklık $55^{\circ} \mathrm{C}$ olduğu koşullarda elde edilmiştir. Ayrıca Noopazyme lipazının 4 kez tekrar kullanılması sonucunda aktivitesinin \%40'ını kaybettiği belirlenmiştir.

Anahtar kelimeler: Alg yağı, Chlorella protothecoides, Hidroliz, Lipaz, Yanıt yüzey yöntemi

\begin{abstract}
Hydrolysis of oils used as the raw material source of many industrial plants is an important chemical process. Fatty acids are synthesized by hydrolysis of oils produced from renewable sources. In recent years, the use of oils derived from microalgae as an alternative to vegetable and animal oils has become commonly increasing. In this study, the effects of the parameters (lipase amount, temperature, oil / water $(w / w)$ ) of Chlorella protothecoides microalgae oil were analyzed to obtain high conversion of free fatty acids with the Design Expert computer program. As a result of the experimental studies, the highest FFA content (98\%) was obtained under the conditions where lipase amount was 15\%, oil/water ratio $(\mathrm{g} / \mathrm{g}) 0.20$ and temperature was $55^{\circ} \mathrm{C}$. In addition, as a result of 4 reuse of Noopazyme lipase, it was determined that it lost $40 \%$ of its activity.
\end{abstract}

Keywords: Algae oil, Chlorella protothecoides, Hydrolysis, Lipase, Response surface methodology

\footnotetext{
* Togayhan KUTLUK; togay71@gmail.com, Tel: (0262) 3033526, orcid.org/0000-0001-7249-9902
} 


\section{Giriş}

Son zamanlarda hayvansal ve bitkisel kaynaklardan elde edilen katı ve sıvı yağların üretimi ve bu yağların kimyasal modifikasyonu sonucu elde edilen ürünlerin (serbest yağ asitleri ve gliserin) endüstriyel boyutlarda üretimi için araştırmalar hız kazanmıştır. Katma değeri yüksek çok sayıda ürünün üretimleri için de yağ asitlerine gereksinim duyulmaktadır. Bunlar, yapıştırıcılar, özel yağlayıcılar, şampuanlar ve diğer kozmetik ürünlerdir. Bitkisel ve hayvansal yağlardan başlıca kozmetik ve diğer birçok endüstriyel alanda kullanılan serbest yă asitleri ve gliserinin sentezlenmesi için başlıca işlem hidrolizdir. Yağların yapısına su molekülleri katılarak bir katalizör (kimyasal veya enzim) yardımı ile yapı birimleri olan yağ asitleri ve gliserol molekülüne dönüştürülmesi işlemine hidroliz denilmektedir.

Hidroliz ile üretilen serbest yă asitleri, kısa zincirli alkoller (metanol veya etanol) ve dallanmış ya da uzun zincirli alkoller (trimetilolpropan veya stearil alkol) ile tepkimeye sokularak farklı fiziksel özelliklere sahip esterler sentezlenebilmektedir. Esterleşme tepkimeleri sonucunda ester ve su molekülleri açığa çıkmaktadır. $\mathrm{Bu}$ tepkime esterlerin üretimi için gereklidir. Çünkü ester üretiminde serbest yă asitlerine ihtiyaç duyulmaktadır. $\mathrm{Bu}$ proses ile bitkisel yağlar, endüstriyel gres kalıntıları, atık pişirme yağları, rafine sıv1 ve katı yağ yan ürünleri ve hatta son y1llarda mikroalglerden ya da makroalglerden elde edilen yağlar hammadde olarak kullanılabilmektedir (Chu vd.,2003; Zenevicz vd., 2016).

Kimyasal katalizörler kullanılarak gerçekleştirilen geleneksel yağ hidrolizi, yüksek sicaklık ve basınçta $\left(250^{\circ} \mathrm{C}\right.$ ve 70 bar) yapılmaktadır (Murty vd., 2002). Yüksek basınç ve sıcaklık nedeni ile tepkime esnasinda istenmeyen yan tepkimeler ortamdaki maddelerin oksidasyonuna, serbest yağ asitlerinin dehidrasyonuna veya trigliseritlerin esterleştirilmesine yol açarak yağların ve yağ asitlerinin yapılarının bozulmasına neden olabilmektedir. (Murty vd., 2002; Rooney ve Weatherley, 2001). Fakat lipazlar tarafindan katalizlenen hidroliz tepkimeleri, enerji tasarrufu sağlamak için daha düşük sıcaklıklarda gerçekleştirilebilirler. Lipazlar, yapıları gereği tek bir tepkimeyi katalizlerler. Bu özelliği ve 1 lımlı koşullarda çalışabilmeleri nedeniyle daha az tepkime yan ürünü oluşurken yüksek kalitede ürünler elde edilebilir (Murty vd., 2002; Castro vd., 2004; Hasan vd., 2009; Sharma vd., 2009). Son yıllarda, araştırmacıların ve büyük ölçekli endüstrilerin (Deterjan, yağ, biyodizel ve yağlama yağ1 üretim tesisleri) lipazlara olan ilgisi geniş uygulama alanları, yüksek seçicilikleri, aynı zamanda 1 lımlı işletme koşulları nedeni ile giderek artmaktadır (Neena, 1997; Yadav ve Borkar, 2009; Yadav vd., 2008; Yadav ve Devi., 2004). Lipazlar varlığında katalizlenen yağların hidroliz tepkimeleri sonucunda yüksek saflıkta mono-di-tri gliseritler ve aynı zamanda geniş endüstriyel uygulama alanına sahip gliserol 1lımlı koşullarda üretilebilmektedir. Lipazlar, ara yüzey enzimleri olmaları nedeni ile hidroliz tepkimelerinde yağ-su ara yüzeyinde oldukça aktiftirler (Yan vd., 2011; Maruyama vd., 2000). Hidroliz tepkimelerinde seçiciliği ve ürün verimini arttırmak için lipazların kullanımı oldukça uygundur (Sharma vd., 2012). Sonuç olarak lipaz katalizli hidroliz tepkimesi geleneksel kimyasal katalizli tepkimeler ile karşılaştırıldığında tepkime sıcaklıkları ve basınçlarında önemli ölçüde azalma sağlarken elde edilen ürün kalitesi de oldukça üstündür. Ekonomik olarak uygulanabilir bir performansta ürün elde edilebilmesi nedeni ile "yeşil kimya" tanımına uygun ve sürdürülebilir teknolojiler için önemli bir proses olacağı düşünülmektedir.

Literatürde lipaz katalizli alg yağının hidroliz tepkimesine etki eden parametreleri detaylica inceleyen bir çalışmaya rastlanmamıştır. Bahadi vd., (2020) yaptıkları çalışmada potasyum hidroksit $(\mathrm{KOH})$ katalizörlüğünde palmiye çekirdeği yağının hidrolizine etki eden parametreleri istatiksel yöntemle incelemişler ve $\% 98$ SYA içeriğine yaklaşık 2 saat tepkime süresi, 1.77 molar $\mathrm{KOH}$ derişimi, $70^{\circ} \mathrm{C}$ tepkime sıcaklığında ulaştıklarını rapor etmişlerdir. Hung vd., (2018) yaptıkları çalışmada bitkisel gac yağının lipaz katalizli hidroliz tepkimesine etki eden parametrelerini araştırmışlar ve deneysel çalışmalar ve optimizasyon sonucunda en yüksek SYA dönüşümünü $(\% 94.16) 38^{\circ} \mathrm{C}$ derece tepkime sicaklığında, \%13.8 enzim varlığında 8 saatte elde ettiklerini belirtmişlerdir. Chen vd., (2014) keten tohumu yağının lipaz katalizli hidrolizi tepkimesine etki eden parametreleri araştırmışlar ve en yüksek SYA dönüşümünü $(\% 93)$ yağ/su oranı 0.9 ve lipaz miktarı \% 1.2 olduğu durumda belirlemişlerdir. Literatürde yapılan çarpıcı çalışmalar neticesinde lipaz katalizli hidroliz tepkimesinin 1lımlı koşullarda yüksek hidroliz verimi ile gerçekleştiği vurgulanmaktadır (Chen vd., 2014).

Hammadde kaynağı olarak kullanılan geleneksel yağların yerine mikro alglerin kullanılması araştırmacıların son yıllardaki ilgi odağı olmuştur. Oldukça yüksek fotosentez potansiyeli ve 
karbondioksit tutma özelliği olan mikro alglerin yaygın kullanım alanı bulunmaktadır. Endüstriyel uygulamanın başlıca biyoteknolojik potansiyeli, alg biyokütlesinin temiz bir biyoyakıt kaynağ 1 olarak görülmesidir. Temel bileşimleri proteinlerden, lipitlerden ve karbohidratlardan oluşan doğada tanımlanmış binlerce alg türü bulunur (Altın, 2017). Mikroalglerin türleri ve yetiştirme koşullarına göre yağ içerikleri \%10-50 arasında değişim göstermektedir. Mikroalg yetiştirilmesi için geniş tarım arazilerine gerek duyulmaması da bir diğer avantajıdır. $\mathrm{Bu}$ özelliklerinden dolayı mikroalgler, endüstride (biyoyakıt üretimi, gıda, kozmetik, ilaç, vb.) ucuz ve doğal bir hammadde kaynağı olarak değerlendirilebilir. Mikroalg yağının Noopazyme katalizörü varlığında enzimatik hidrolizine etki eden tepkime parametreleri (lipaz miktarı, sıcaklık, yağ/su (g/g)) yüksek verimle serbest yağ asitleri elde edilmesi amaçlanmıştır. Bu amaçla tepkime Design Expert 7.0.0 paket programı ile Yanit Yüzey Yöntemi'nin Merkezi Kompozit Tasarımı (CCD: Central Composite Design) kullanılarak modellenmiştir. Yanıt Yüzey Yöntemi, matematiksel ve istatiksel analizler çerçevesinde problemin modellenmesi ve çözümlenmesini sağlarken çeşitli parametre ve değişkenlerin de bu sonuçlara olan etkilerini belirlememizi sağlar. Bu kapsamda amaç, kullanılan değişkenlerin (girdi değişkenleri veya faktörler) etkilediği yanıtın (çıtı değişkenleri) iyileştirilmesidir. $\mathrm{Bu}$ yöntem, ikinci dereceden bir yüzeyin belirlenerek uyumlaştırılması için uygundur ve en az sayıda deney ile etkin parametrelerin belirlenerek kesinleştirilmesine yardım ederken değişkenler arasındaki etkileşimi de analiz eder. Tepkime parametrelerinin hidroliz verimi üzerindeki etkilerinin tanımlanması için, programın önerdiği CCD'ye dayalı olarak seri deneyler yapılmıştır. Deneysel sonuçlar programa tanımlanarak Denklem 1'e göre program tarafindan değişkenlerin kodlanmış değerleri belirlenmiştir.

$$
x i=\frac{x i-x o}{\Delta x}
$$

Burada, xi - i değişkeninin kodlanmış değeri, Xi kodlanmamış i'inci değeri, Xo test değişkeninin kodlanmamış değeri ve i merkez noktasıdır. Bir ikinci mertebeden polinom denklemi; bağımsız değişkenlerin bir fonksiyonu olarak hidroliz verimini (Y) ve aslında Denklem 2'yi ifade eder.

$$
Y=\mathrm{bo}+\sum_{i=1}^{k} \mathrm{biXi}+\sum_{i=1}^{k} \mathrm{bijX}^{2}+\sum_{\mathrm{i}_{1}<j}^{\mathrm{k}} \sum_{\mathrm{j}}^{\mathrm{k}} \mathrm{b}_{\mathrm{i}} \mathrm{X}_{\mathrm{i}} \mathrm{X}_{\mathrm{J}}+\mathrm{e}
$$

Burada Y, tepki faktörüdür (\% serbest yağ asidi içeriği) ve $i$ ve $j$ sırasıyla doğrusal ve ikinci dereceden katsayıları temsil etmektedir. Denklemde bo, kesişim, bi birinci dereceden model katsayıs1, k faktörlerin sayıs1 ve e'nin rastgele bir sayı olduğu bilinmektedir.

Regresyon analizi, yanıt fonksiyonunu bir ikinci dereceden polinomu belirlemek ve tahmin edebilmek için yapılmıştır. Deneysel sonuçlardan elde edilen verilerin regresyon analizi ve regresyon denkleminin katsayı değerinin tahmin edilmesi program yardımıyla gerçekleşmiştir. Modelin yeterliliği varyans analizi (ANOVA) kullanılarak belirlenmiştir. Test değişkenlerinin serbest yă asidi içeriği üzerindeki bireysel ve etkileşimli etkilerini açıklamak için program tarafından tepki yüzeyleri oluşturularak yorumlanmıştır (Russel, 2009).

$\mathrm{Bu}$ çalışmada bitkisel ve hayvansal yağlara alternatif olarak kullanılması öngörülen Chlorella protothecoides mikroalg yağının enzim katalizli çevre dostu hidroliz prosesi ile işlenerek serbest yağ asitleri üretilmesi ve hidroliz tepkimesine etki eden önemli parametrelerin (lipaz miktarı, sıcaklık, yağ/su (g/g)) tespit edilmesi ve iyileştirilmesi amaçlanmıştır. Bu amaç ile hidroliz tepkimesine etki eden parametreler ve bu parametreler arasındaki etkileşimleri ortaya koyabilmek için istatiksel deney tasarımı uygulanarak sonuçların optimizasyonu sağlanmıştır. Deneysel çalışmalar sonucunda yüksek içerikte serbest yağ asitleri elde edilmiş ve serbest yağ asidi profili belirlenmiştir. Ayrıca tepkimelerde katalizör olarak kullanılan ticari tutuklanmış lipaz Noopazyme'in tekrar kullanılabilirliği incelenmiştir.

\section{Gereç ve yöntem}

\subsection{Malzemeler}

Hidroliz tepkimesi araştırmalarında kullanılan alg yağ 1 (Chlorella protothecoides) Soley firmasından hibe edilmiştir. Ticari tutuklanmış lipaz katalizörü Noopazyme, Novozyme firmasindan hibe edilmiştir. Analizlerde kullanılan ve adı geçen diğer kimyasallar ( $\mathrm{NaOH} \% 99$, n-Hekzan \%99), Merck firmasının Türkiye temsilcisinden satın alınmıştır.

\subsection{Serbest yă̆ asitleri sentez tepkimeleri}

Mikroalg yağından lipaz katalizli hidroliz tepkimesi ile serbest yağ asitleri (SYA) üretilmesi amacı ile tepkimeye etki eden en önemli faktörler (yağ/su oranı $(0.05-0.20 \% \mathrm{~g} / \mathrm{g})$, lipaz miktarı (\% 
0.15-0.50 (\%g yağa göre)), sicaklık $\left(30-55^{\circ} \mathrm{C}\right)$, karıştırma hızı) araştırılmıştır. Tepkimeler INNOVA 40 marka soğutuculu çalkalamalı inkübatörde 25ml'lik ağzı kapalı erlenlerde eş zamanlı gerçekleştirilmiştir. Her tepkime için $3 \mathrm{~g}$ yağ temel alınarak diğer reaktanlar ve katalizör miktarları hesaplanmıştır. Her tepkime için $3 \mathrm{~g}$ yağ temel alınmasının nedeni küçük hacimli seri tepkimeler yaparak elimizde bulunan k1sitl hammaddenin etkin bir şekilde kullanılabilmesi içindir. Aynı zamanda tüm deneylerde tepkime hacmini sabit tutarak ölçek büyütme veya küçültme işleminden gelecek olan olası hataların önüne geçmek içindir. Tepkime süresi 24 saat, karıştırma h1z1 400 dev/dk'dır.

\subsection{Yă̆ asidi içeriği ve profilinin belirlenmesi}

Serbest yağ asidi profili, alev iyonizasyon dedektörü (FID) ve $30 \mathrm{~m}$ x $320 \mu \mathrm{m}$ x $0.25 \mu \mathrm{m}$ kapiler kolon (CARBOWAX 20M) ile Agilent 7820 A model gaz kromatografi (GC) cihazı kullanılarak belirlenmiştir. Dedektör sıcaklığ $280^{\circ} \mathrm{C}$ ve split oranı 1:50'dir. Kolon sicaklığ $1,50^{\circ} \mathrm{C}$ 'de 1 dakika beklemeden sonra dakikada $25^{\circ} \mathrm{C} / \mathrm{dk}$ artışla $200^{\circ} \mathrm{C}^{\prime}$ ye $3^{\circ} \mathrm{C} / \mathrm{dk}$ artışla $230^{\circ} \mathrm{C}^{\prime}$ ye ulaşılarak bu sıcaklıkta 18 dakika bekletilerek $40^{\circ} \mathrm{C} / \mathrm{dk}$ artışla $280^{\circ} \mathrm{C}^{\prime}$ ye çıkılarak ve bu sicaklıkta da 3 dakika kalacak şekilde ayarlanmıştır. Helyum taşıyıcı gaz olarak kullanılmıştır. Cihaza enjekte edilecek örnek için yağların metil esterleri haline getirilmesi gerekmektedir. $\mathrm{Bu}$ amaçla 0.1 gram yağ örneği, $20 \mathrm{ml}$ 'lik cam tüp içerisine tartılarak ve üzerine $10 \mathrm{ml}$ n-hekzan ilave edilerek çözülmüștür. Daha sonra üzerine $2 \mathrm{~N}$ potasyum hidroksit çözeltisinden $100 \mu$ eklenip, yarım dakika kadar vortekslenmiştir. Karışım santrifüj edilerek (5000 rpm, $5 \mathrm{dk}$ ) üst fazdan alınan $1 \mu \mathrm{l}$ örnek ile cihaza enjeksiyon yapılmıştır (David vd., 2005).

\subsection{Biyokatalizörün tekrar kullanılabilirliği}

Hidroliz tepkimesi sonucunda ürünler santrifüj (6000dev/dk, 10dk) yardımı ile tepkime ortamından ayrılmıştır. Santrifüj sonucunda üst faz serbest yağ asitleri ve gliserin içermektedir. Gliserin fazı beyaz görünümlüdür. Alt fazda olan lipazlar ayrıldıktan sonra $3 \mathrm{kez} 5 \mathrm{ml}$ 'lik enjektör yardımı ile \%99 saflıkta n-hekzan ile yıkanarak petri kabına aktarılmıştır. Lipazlar sonraki tepkimelerde kullanılmak üzere $+4^{\circ} \mathrm{C}^{\prime} \mathrm{de}$ buzdolabında saklanmıştır. Üst fazdaki serbest yağ asidi ve gliserin ayırma hunisi yardımı ile ayrılmıştır.

\subsection{Biyokatalizörün aktivitesinin belirlenmesi}

Noopazyme enziminin aktivitesi yaygın kullanılan bir yöntem olan zeytinyağı hidrolizi ile belirlenmiştir. Bir ünite enzim (U), zeytinyağından $1 \mathrm{dk}$ 'da $1 \mu \mathrm{mol}$ yağ asidi hidroliz eden lipaz miktarı olarak tanımlanmıştır. Tepkime ortamı $25 \mathrm{ml}$ hacmindeki erlenlerde $2.5 \mathrm{ml}$ zeytinyağ 1 ve $2.5 \mathrm{ml}$ fosfat tamponu (0.1M, pH7.0) çalkalamalı inkübatörde $37^{\circ} \mathrm{C}$ 'ye kadar 1 sitılmıştır. $0.1 \mathrm{~g}$ Noopazyme tartilarak tepkime ortamina eklenmiştir. Hidroliz tepkimesi $30 \mathrm{dk}$ boyunca sürdürülmüş olup sonlandırmak için hacimce 1:1 oranında hazırlanmış eter/etanol karışımından $2.5 \mathrm{ml}$ ortama eklenmiștir. Daha sonra 1-2 damla olacak şekilde \%1'lik fenolftalein indikatörü ortama eklenerek $0.1 \mathrm{M} \mathrm{NaOH}$ çözeltisi ile titre edilmiştir. Harcanan $\mathrm{NaOH}$ çözeltisi hacminden Denklem 3'e göre hesaplanmıștır. Titrasyonlar güvenilirliği arttırmak adına 5 tekrar yapılarak ortalaması alınmıştır (Stoytcheva vd., 2012; Özgen, 2013).

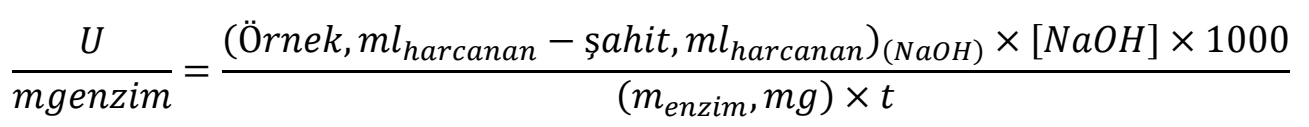

\subsection{Yanit yüzey yöntemi uygulanarak lipaz katalizli hidroliz tepkime parametrelerinin modellenmesi ve optimize edilmesi}

Noopazyme varlığında gerçekleştirilen hidroliz tepkimesine etki eden üç önemli faktör (lipaz miktarı, sıcaklık, yağ/su (g/g)) yapılan ön deneyler sonucunda bağımsız değişkenler olarak seçilmiştir. Tepkime süresi 24 saat, karıştırma hızı 400 dev/dk. olarak belirlenmiştir. Bağımsız değişkenlerin birleşmiş etkileri incelendiğinde, serbest yağ asidi dönüşümü ampirik modeli geliştirmek için kullanılan bağımlı değişkendir ve modelin yanıtını teşkil etmektedir. En yüksek yanıt değeri için en iyi koşulların belirlenmesi amaçlanmıştır. CCD genelde altı merkezli bir tasarım olup, $2 n$ faktöriyel çalışma ve 2(n) eksenel koşul içerir, burada $n$ faktör sayısıdır. Deneyler $25 \mathrm{ml}$ 'lik ağzı alüminyum folyo ve parafilmle ile kapatılmış erlenlerle IKA marka çalkalamalı inkübatörde yapılmıştır. Tepkimeye etki eden parametrelerin kodlanmış ve gerçek değerlerini gösteren program verileri Tablo 1 'de, program tarafindan öngörülen 20 deney seti Tablo 2'de verilmiştir. 
Tablo 1. Noopazyme katalizörlüğünde mikroalg yağının hidroliz tepkimesi ile serbest yağ asitlerinin sentezi için etki eden parametrelerin kodlanmış ve gerçek değerleri

\begin{tabular}{lcccccc}
\hline Faktör & $\begin{array}{l}\text { En düşü̈k } \\
\text { değer }\end{array}$ & $\begin{array}{l}\text { En yüksek } \\
\text { değer }\end{array}$ & $\begin{array}{l}\text { Kodlanmış en } \\
\text { düşük değer }\end{array}$ & $\begin{array}{l}\text { Kodlanmış en } \\
\text { yüksek değer }\end{array}$ & Ortalama & $\begin{array}{l}\text { Standart } \\
\text { sapma }\end{array}$ \\
\hline $\begin{array}{l}\text { A: Enzim Miktarı } \\
\text { (\%gr yağa göre) }\end{array}$ & 0.15 & 0.50 & -1.00 & 1.00 & 0.325 & 0.145 \\
B: Yağ/su oran1 $(\mathrm{g} / \mathrm{g})$ & 0.050 & 0.20 & -1.00 & 1.00 & 0.125 & 0.062 \\
C: S1caklık $\left({ }^{\circ} \mathrm{C}\right)$ & 30 & 55.0 & -1.00 & 1.00 & 42.50 & 10.329 \\
\hline
\end{tabular}

Tablo 2. Etki eden parametreler ve kodlanmış değerlerini içeren deney seti

\begin{tabular}{ccccc}
\hline $\begin{array}{c}\text { Deney } \\
\text { numarası }\end{array}$ & $\begin{array}{c}\text { Faktör A: Enzim Miktarı } \\
\text { (\%gr yağa göre) }\end{array}$ & $\begin{array}{c}\text { Faktör B: yağ/su } \\
\text { oranı }(\mathbf{g} / \mathbf{g})\end{array}$ & $\begin{array}{c}\text { Faktör C: } \\
\text { Sicaklık }\left({ }^{\circ} \mathbf{C}\right)\end{array}$ & Yanıt: \% SYA \\
\hline 1 & 0.32 & 0.13 & 42.50 & 94 \\
2 & 0.32 & 0.25 & 42.50 & 95 \\
3 & 0.32 & 0.13 & 42.50 & 93 \\
4 & 0.50 & 0.20 & 55.00 & 96 \\
5 & 0.32 & 0.13 & 42.50 & 92 \\
6 & 0.03 & 0.13 & 42.50 & 90 \\
7 & 0.32 & 0.13 & 42.50 & 98 \\
8 & 0.50 & 0.05 & 55.00 & 83 \\
9 & 0.15 & 0.05 & 30.00 & 93 \\
10 & 0.62 & 0.13 & 42.50 & 84 \\
11 & 0.50 & 0.20 & 30.00 & 87 \\
12 & 0.50 & 0.05 & 30.00 & 97 \\
13 & 0.15 & 0.05 & 55.00 & 99 \\
14 & 0.32 & 0.13 & 63.52 & 73 \\
15 & 0.32 & 0.13 & 21.48 & 92 \\
16 & 0.32 & 0.13 & 42.50 & 97 \\
17 & 0.15 & 0.20 & 55.00 & 90 \\
18 & 0.32 & 0.13 & 42.50 & 81 \\
19 & 0.15 & 0.20 & 30.00 & 92 \\
20 & 0.32 & 0.13 & 42.50 & \\
\hline
\end{tabular}

\section{Bulgular ve tartışma}

\subsection{Tepkime süresinin belirlenmesi}

Chlorella protothecoides mikroalg yă̆ının Noopazyme katalizörü varlığında hidroliz tepkime süresinin belirlenmesi amaciyla $55^{\circ} \mathrm{C}$ tepkime sicaklığında, yağ/su oranı 0.10 ve enzim miktarı $\% 0.15$ olduğu koşullarda 24 saat süre ile deney yapılmıştır. Şekil 1'den açıkça görüldüğü üzere serbest yağ asidi miktarı 24 saate kadar artarak en yükssek içeriğe (\%91) ulaşmış bu zamandan sonra belirgin bir değişim göstermemiştir. Tepkime süresi 24 saat olarak belirlenerek optimizasyon çalışması deneyleri 24 saat üzerinden tasarlanmıştır.

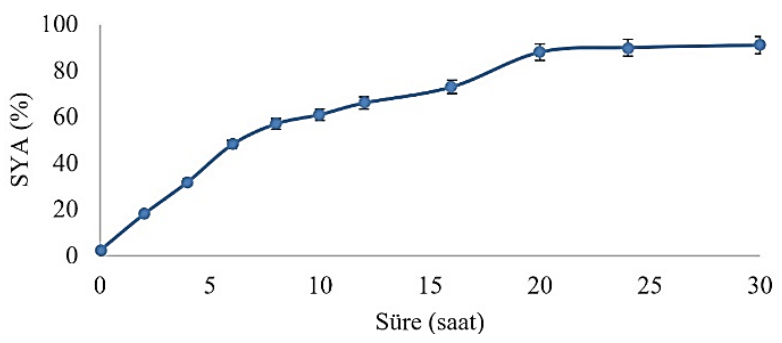

Şekil 1. Hidroliz tepkimesinde sürenin SYA dönüşümüne etkisi

\subsection{Karıştırma hizının belirlenmesi}

Kimyasal tepkimelerde optimum karışma ile tepkime ortamında kütle aktarım kısıtlamalarının önüne geçilerek yăg/su ara yüzeyinde gerçekleşen hidroliz tepkimesi için optimum verim sağlanmış olur. Düşük karıştırma hızlarında lipaz sıvı faz içinde homojen dağılamaz ya da yüksek hızlarda 
reaktör çeperlerinden yukarı yönelerek yapışır. Bu tür karıştırma problemleri düşük verimlere neden olurlar (Xin vd., 2008). Lipaz katalizli mikroalg yağının hidrolizine karıştırma hızının etkisini incelemek amac $55^{\circ} \mathrm{C}$ tepkime sicaklığında, yağ/su oran1 0.10 , enzim miktarı $\% 0.15$ olduğu koşullarda, 24 saat süre ile 200-250-300-350-400450-500 rpm karıştırma hızlarında deneyler yapılmışıtır. Karıştırma hızının SYA içeriğine etkisi Şekil 2'de verilmiştir.

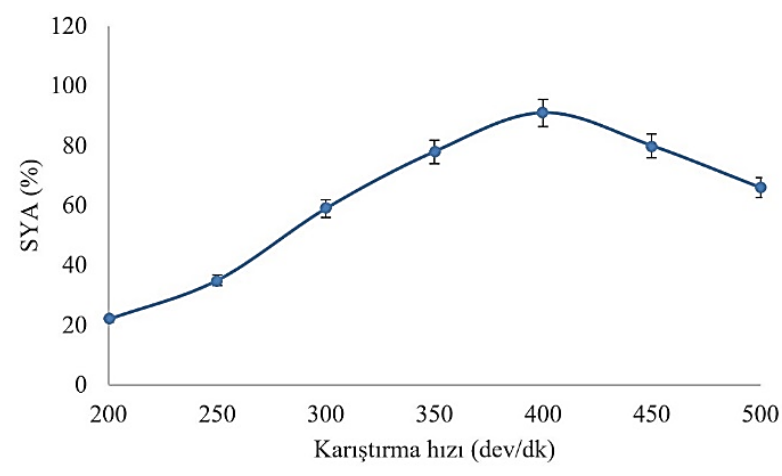

Şekil 2. Hidroliz tepkimesinde zamanın SYA dönüşümüne etkisi
Karıştırma hızı arttıkça serbest yağ asidi içeriği belirgin bir şekilde artış göstermiştir. Karıştırma hızı 400rpm olduğu durumda en yüksek (\%91) serbest yăg asidi içeriğine ulaşılmıştır. Düşük karıştırma hızları kütle aktarım kısıtlamalarının aşılmasında yeterli olmadığı aynı zamanda yüksek hızlarda katalizörün tepkime ortamı çeperlerine yapışarak ortamdan uzaklaştı̆̆ görülmüştür.

\subsection{Anova analizi}

Noopazyme katalizörü varlığında gerçekleşen hidroliz tepkimesi için program tarafından tasarlanan model analizi Tablo 3'te gösterilmiştir. Program, lipaz katalizli hidroliz tepkimesi için kuadratik (2. dereceden) modeli önermiştir. Enzim katalizli tepkimelerde CCD'nin tam bir kübik modeli desteklemek için yeterli olmağ 1 bilinmektedir. Parametrelerin birbirleri aras1 etkileşimin olduğu tepkime setlerinde genellikle önerilen durum ikinci dereceden bir matematiksel model ile tanımlanmasıdır. Önerilen modelin uygunluğu istatiksel olarak desteklenmektedir. Önerilen modelin lack of fit test sonuçları Tablo 4'te verilmiştir.

Tablo 3. Noopazyme katalizörlüğünde mikroalg yağının hidroliz tepkimesi için model istatistik verileri

\begin{tabular}{ccccc}
\hline Model & Standart sapma & $\mathbf{R}^{\mathbf{2}}$ & Hesaplanmış $\mathbf{R}^{\mathbf{2}}$ & Öngörülen $\mathbf{R}^{\mathbf{2}}$ \\
\hline Doğrusal & 2.63 & 0.86 & 0.83 & 0.76 \\
2FI & 2.81 & 0.87 & 0.81 & 0.70 \\
2. Derece & 1.81 & 0.96 & 0.92 & 0.76 \\
Kübik & 1.22 & 0.98 & 0.96 & 0.96 \\
\hline
\end{tabular}

Tablo 4. Noopazyme katalizörlüğünde mikroalg yağının hidroliz tepkimesi için Yanıt Yüzey Yöntemi lack of fit test sonuçları

\begin{tabular}{cccccc}
\hline Model & Kareler toplamı & df & Kareler ortalaması & F değeri & $\begin{array}{c}\text { p-değeri } \\
\text { olasılık }>\text { F }\end{array}$ \\
\hline Doğrusal & 102.22 & 11 & 9.29 & 5.26 & 0.039 \\
2FI & 93.85 & 8 & 11.73 & 6.64 & 0.026 \\
2. Derece & 23.83 & 5 & 4.77 & 2.70 & 0.150 \\
Kübik & 0.075 & 1 & 0.0075 & 0.0042 & 0.845 \\
\hline
\end{tabular}

Program tarafindan önerilen modelin lipaz katalizli hidroliz tepkimesinin ANOVA analizi Tablo 5'te verilmiştir. Tablodaki model değişkenlerinin hepsinin anlamlı olduğu görülmektedir. Önerilen model için F (gerileme) değeri 26.16 olarak belirlemiştir. $\mathrm{F}$ değerleri, modelin önemli olduğunu; bu da p- 0.0001'den düşük değerlerde modelin önemli ölçüde uygunluğunu göstermektedir (Kumar vd., 2003). Tepkimeye etki eden faktörler ve ikili etkileşimlerinden hangilerinin $\mathrm{p}$ değerleri 0.0001 'den düşük ise tepkimeye önemli etkisinin olduğu anlaşılmaktadır. Ayrıca hidroliz tepkimesine etki eden en önemli faktörün sicaklık olduğu $(\mathrm{p}-<$ $0.0001, \quad \mathrm{~F}=209.74)$ da bu tablodan anlaşılmaktadır. 
Tablo 5. Noopazyme katalizörlüğünde mikroalg yağının hidroliz tepkimesi için modelin ANOVA analiz verileri

\begin{tabular}{cccccc}
\hline Faktör & $\begin{array}{c}\text { Kareler } \\
\text { toplamı }\end{array}$ & df & $\begin{array}{c}\text { Ortalama } \\
\text { kareler }\end{array}$ & F değeri & $\begin{array}{c}\text { P değeri } \\
\text { olasilık }>\text { F }\end{array}$ \\
\hline Tüm Model & 769.14 & 9 & 85.46 & 26.16 & $<0.0001$ \\
A & 5.52 & 1 & 5.52 & 1.69 & 0.2228 \\
B & 0.15 & 1 & 0.15 & 0.045 & 0.8372 \\
C & 685.08 & 1 & 685.08 & 209.74 & $<0.0001$ \\
AB & 1.12 & 1 & 1.12 & 0.34 & 0.5703 \\
AC & 6.12 & 1 & 6.12 & 1.88 & 0.2008 \\
BC & 1.13 & 1 & 1.13 & 0.34 & 0.5703 \\
$\mathrm{~A}^{2}$ & 0.32 & 1 & 0.32 & 0.09 & 0.7590 \\
$\mathrm{~B}^{2}$ & 0.32 & 1 & 0.32 & 0.09 & 0.7590 \\
$\mathrm{C}^{2}$ & 66.49 & 1 & 66.49 & 20.36 & 0.0011 \\
\hline
\end{tabular}

Ayrıca F değerleri yüksek ve $p$ değerleri de buna karşın düşük ise modelin uygunluğunun o derece iyi olduğu belirtilir. $\mathrm{Bu}$ oran Adeq. Precision, sinyal / gürültü olarak tanımlanır. Önerilen modelin uygunluğu için bu oranın 4'ten büyük bir değer olması beklenmektedir. Lipaz katalizli hidroliz tepkimesi için önerilen modelin oran 19.02'dir (Tablo 6).

Tablo 6. Hidroliz tepkimesine ait önemli model değerleri

\begin{tabular}{ll}
\hline Standart sapma & 1.81 \\
Ortalama & 90.90 \\
C.V. \% & 1.99 \\
Hesaplanmış R ${ }^{2}$ & 0.93 \\
Öngörülen $\mathrm{R}^{2}$ & 0.75 \\
Sinyal gürültü oranı & 19.02 \\
\hline
\end{tabular}

Bu değer 4'ten uzaklaştıkça modelin uyumluluğu da kuvvetlenmektedir. Ayrica modelin uygunluğu öngörülen değerler ile gerçek değerler arasındaki ilişkiye de bağlı olduğu bilinmektedir. $\mathrm{R}^{2}$ değeri ne kadar 1'e yakın ise istatistiksel veriler ve öngörüler o derece gerçekle örtüşmektedir. Hidroliz tepkimesi için Noopazyme katalizörlüğünde bu değer (Adjusted $\mathrm{R}^{2}$ ) 0.92 olduğu belirlenmiştir (Yuan vd., 2008; Shrivastsvs, 2008). Ayrica, model tasarlanırken değişken aralıkları ne derece dar seçilirse hesaplanmış ve öngörülen $\mathrm{R}^{2}$ değerleri birbirlerine yaklaşmaktadır. Enzim katalizörü varlığındaki tepkimelerde tepkimeye etki eden değişkenlerin aralıklarının dar tutulması öngörülen $\mathrm{R}^{2}$ değerini hesaplanmış $\mathrm{R}^{2}$ değerlerine yaklaştırırken enzimler üzerine tepkime sıcaklığının önemli ölçüde etkisinin olduğu düşünüldüğünde aralıkların dar tutulması deneysel tasarım yapilırken yanıltıcı olabilmektedir (Montgomery vd., 2012).

Noopazyme katalizörlüğünde gerçekleşen hidroliz tepkimesi için model tarafından hesaplanan olasılık grafikleri sırasıyla Şekil 3'de, öngörülen sonuçlar ile gerçek değerler arasında çizilen grafik ise Şekil 4'de verilmiştir. Düz çizgiler boyunca dağılım gösteren noktaların, deneysel elde edilen sonuçlar ve yanıtın öngörülen değerleri arasında iyi bir ilişki olduğunu kanıtlamaktadır. Ayrıca seçilen tüm modellerin deneysel değerlerdeki yanıt değişkenlerinin öngörülmesi için yeterli olduğu görülmektedir. 


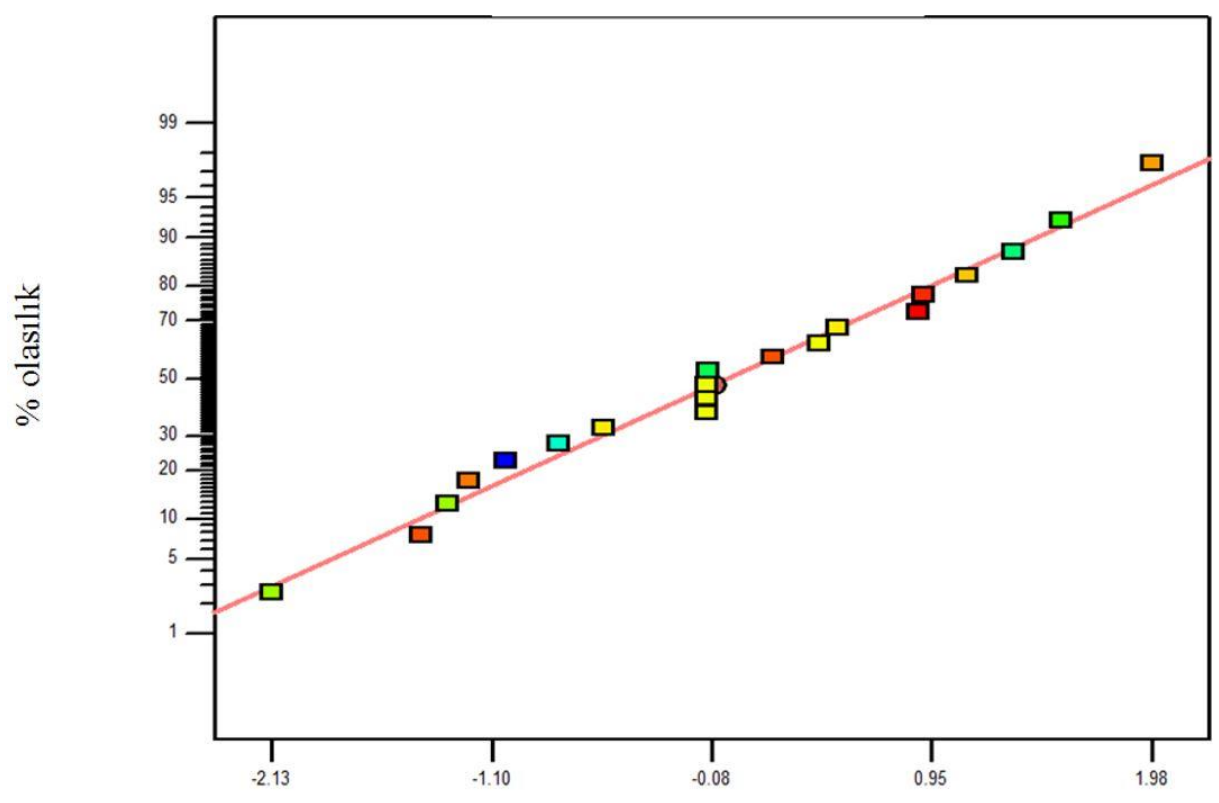

Standart edilmiş

Şekil 3. Noopazyme katalizörlüğünde hidroliz tepkimesi için olasılık grafiği

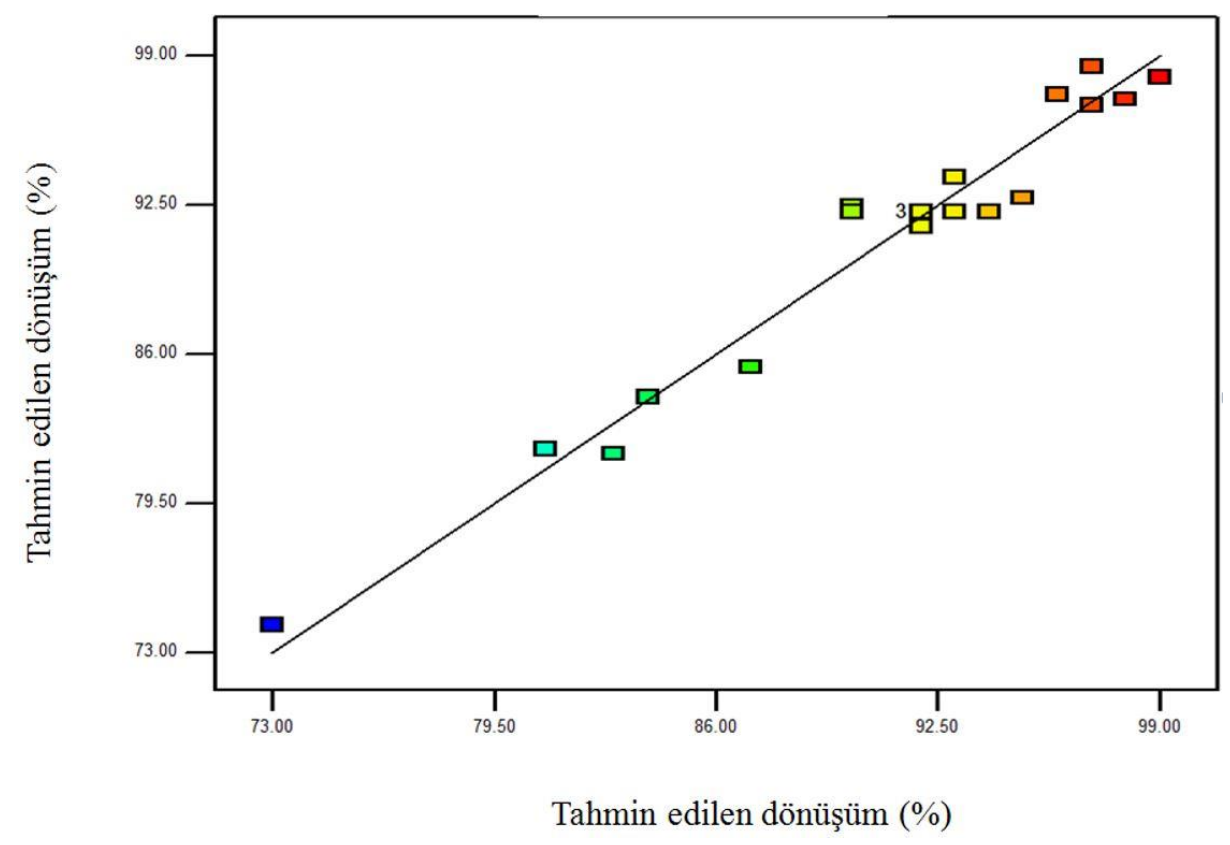

Şekil 4. Hidroliz tepkimesi için tahmin edilen ve gerçek dönüşüm karşılaştırması

Hidroliz tepkimesi için program tarafindan oluşturulan ve tüm parametrelerin etkileşiminin tanımlandığı model denklemi denklem 4'te verilmiştir. Ayrıca parametrelerin birbirleri arasında etkileşimi incelendiğinde; düşük sıcaklıklarda hidroliz veriminin ya da diğer bir deyişle elde edilen serbest yă̆ asidi miktarının azaldığı, aynı zamanda sıcaklık ve yağ/su oranı birlikte arttığında SYA dönüşümünün arttığı, birlikte azalması ile de düştüğü grafikten açıkça görülmektedir (Şekil 3a-3b-3c).

SYA $=+92.16+0.64 * \mathrm{~A}+0.10 * \mathrm{~B}+7.08 * \mathrm{C}-0.37 * \mathrm{~A} * \mathrm{~B}-0.87 * \mathrm{~A} * \mathrm{C}+0.38 * \mathrm{~B} * \mathrm{C}+$ $0.15 * \mathrm{~A} 2+0.15 * \mathrm{~B} 2-2.15 * \mathrm{C} 2$

Sıcaklık ve yağ/su oranının birbirleri ile etkileşimi incelendiğinde, enzim miktarı $\% 0.15$, sicaklık $55^{\circ} \mathrm{C}$, yă $/$ su oran 0.05 olduğu durumda en yüksek (\%97) SYA dönüşümü elde edilmiştir. Enzim 
miktarı aynı kalır iken sıcaklık $30^{\circ} \mathrm{C}$, yağ/su oranı 0.20 olduğu durumda en düşük (\%81) SYA dönüşümü elde edilmiştir (Şekil 5a). Enzim miktarı $\% 0.32$, sicaklık $42.5^{\circ} \mathrm{C}$, yağ/su oran1 0.13 olduğu durumda en yüksek (\%95) SYA dönüşümü elde edilmiştir. Enzim miktarı aynı kalır iken sıcaklık $22^{\circ} \mathrm{C}$, yağ/su oranı 0.13 olduğu durumda en düşük

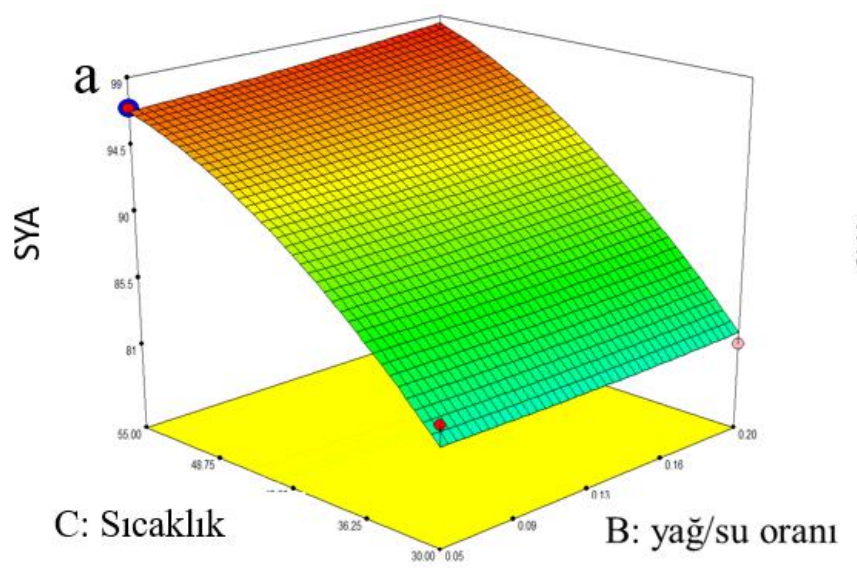

(\%73) SYA dönüşümü elde edilmiştir (Şekil 5b). Enzim miktar $\% 0.50$, sicaklık $55^{\circ} \mathrm{C}$, yağ/su oran 0.05 olduğu durumda en yüksek (\%98) SYA dönüşümü elde edilmiştir. Enzim miktarı aynı kalır iken sicaklık $30^{\circ} \mathrm{C}$, yağ/su oranı 0.20 olduğu durumda en düşük (\%83) SYA dönüşümü elde edilmiştir (Şekil 5c).

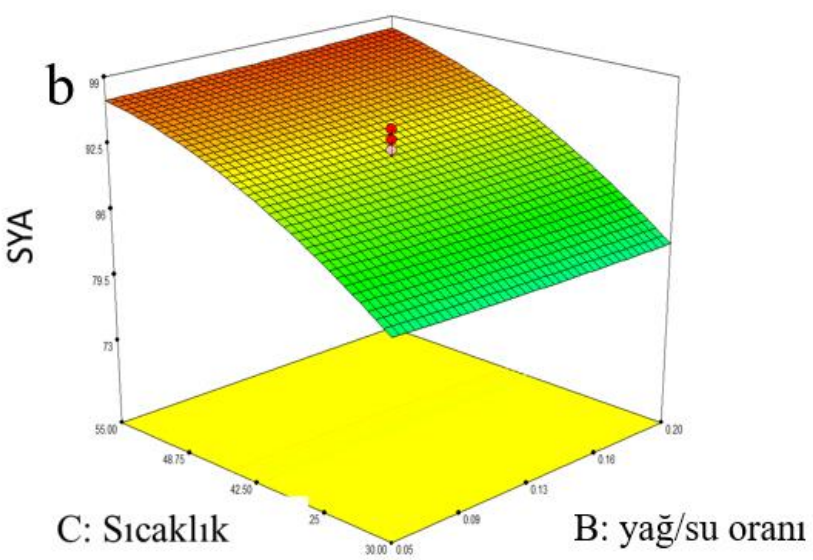

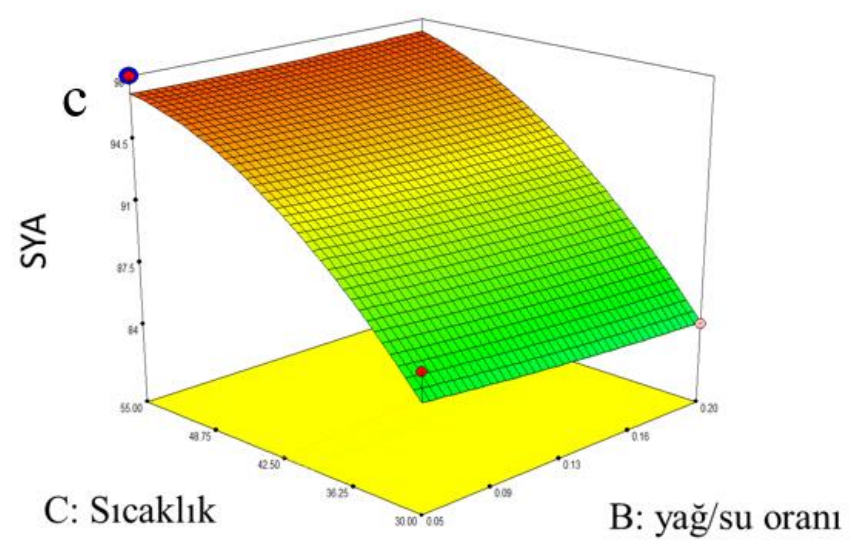

Şekil 5. Sıcaklık ve yağ/su oranının SYA dönüşümüne birlikte etkisi a) Enzim miktarı \%0.15, b) Enzim miktarı $\% 0.33$, c) Enzim miktarı \%0.50

Diğer yandan enzim miktarı ve yağ/su oranının SYA dönüşümüne birlikte etkisi incelendiğinde enzim miktarının artması veya azalmasının belirgin bir etkisi olmadığı parametrelerin birbirleri arasında sinırlayıcı bir etkisinin olmadığ anlaşılmaktadır (Şekil 6a-6b-6c).

Yağ/su oranı ve enzim miktarının birbirleri ile etkileşimi incelendiğinde, sıcaklık $30^{\circ} \mathrm{C}$, yağ/su oranı 0.05 , enzim miktarı 0.50 olduğu durumda en yüksek (\%87) SYA dönüşümü elde edilmiştir. Sıcaklık aynı kalır iken enzim miktarı 0.15 , ya ğ/su oran1 0.20 olduğu durumda en düşük (\%81) SYA dönüşümü elde edilmiştir (Şekil 5a). Sicaklık $42.5^{\circ} \mathrm{C}$, yağ/su oran1 0.13 , enzim miktarı 0.32 olduğu durumda en yüksek (\%94) SYA dönüşümü elde edilmiştir. Sıcaklık aynı kalır iken enzim miktarı ile yağ/su oranındaki değişimlerin SYA dönüşümüne belirgin bir etkisinin olmadığ görülmüştür (Şekil 5b). Sicaklık $55^{\circ} \mathrm{C}$, yağ/su oranı 0.05 , enzim miktarı 0.50 olduğu durumda en yüksek (\%98) SYA dönüşümü elde edilmiştir (Şekil 5c). Bu grafikten anlaşıldığ üzere tepkime sıcaklığının SYA dönüşümü üzerine belirgin bir etkisinin olduğu anlaşılmaktadır. Tepkime ortamında enzim miktarı arttıkça dönüşüm azalmaktadır çünkü ortamda bulunan fazla enzim birbirleri arasında topaklaşma yaparak aktivitelerini kaybetmektedirler. Tepkime sıcaklığı ve yağ/su oranının birbirleri ile etkileşimi incelendiğinde hidroliz verimine belirgin bir etkisinin olmadığ görülmektedir. Yağ/su oranı ve enzim miktarının birbirleri arasındaki etkileşimi incelendiğinde hidroliz verimine belirgin bir etkisinin olmadığı görülmektedir. Hidroliz tepkimesi için en önemli parametrenin sıcaklık olduğu belirlenmiştir. 

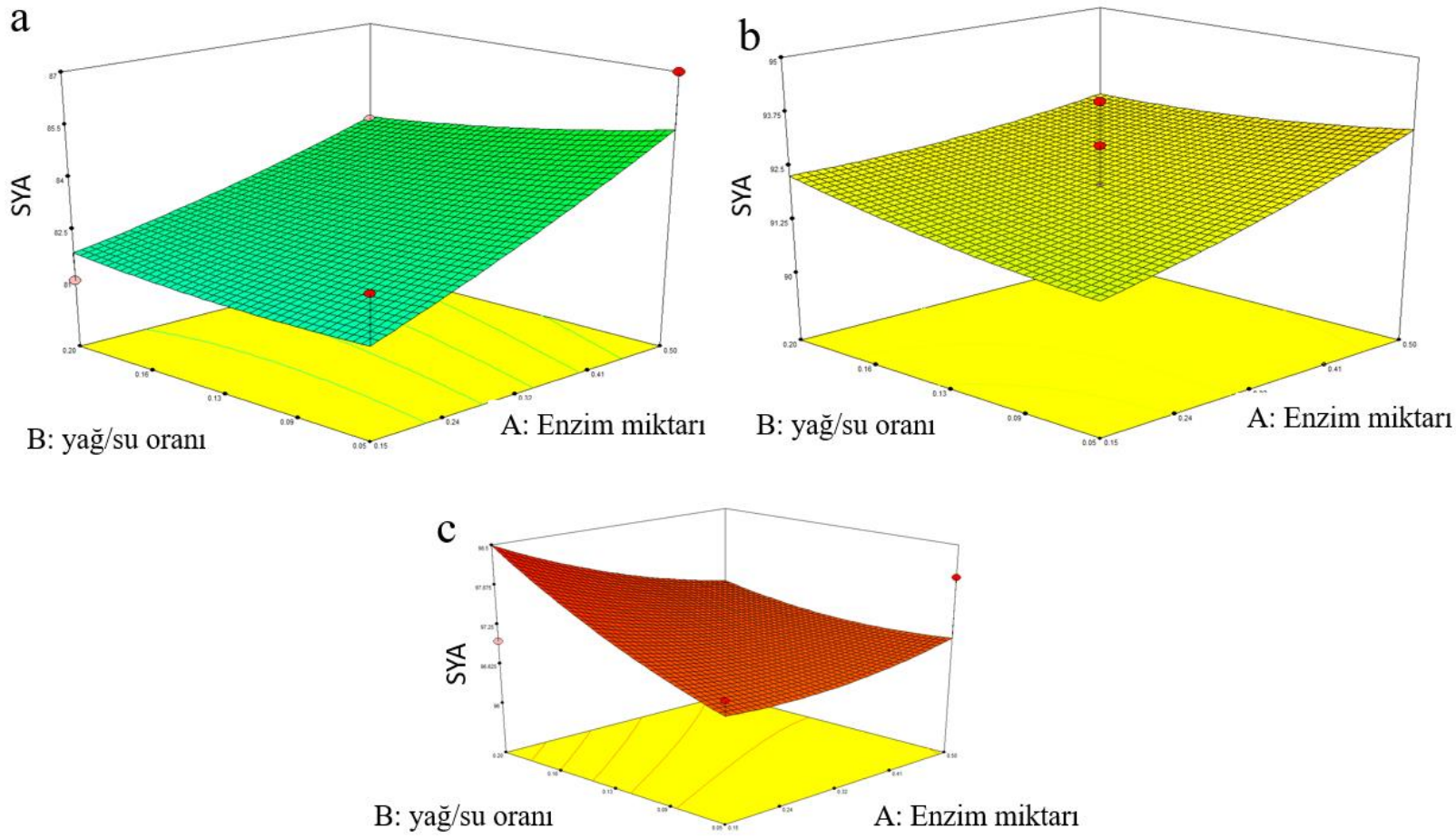

Şekil 6. Enzim miktarı ve yağ/su oranının SYA dönüşümüne birlikte etkisi a) Sicaklık $30^{\circ} \mathrm{C}$, b) Sicaklık $42.50^{\circ} \mathrm{C}$, c) Sicaklik $55^{\circ} \mathrm{C}$

Noopazyme katalizörü varlığında hidroliz tepkimesi için, model optimizasyonu sonucunda iyileştirme ile \%15 lipaz, yağ/su oran $1(\mathrm{~g} / \mathrm{g}) 0.20 \mathrm{ve}$ sicaklık $55^{\circ} \mathrm{C}$ koşulları için program yanıtı (SYA dönüşümü) \%98 olarak belirlenmiştir (Şekil 7). Optimizasyon çalışması sonucunda en etkili parametrelerin sicaklık ve enzim miktarı olduğu belirlenmiştir.

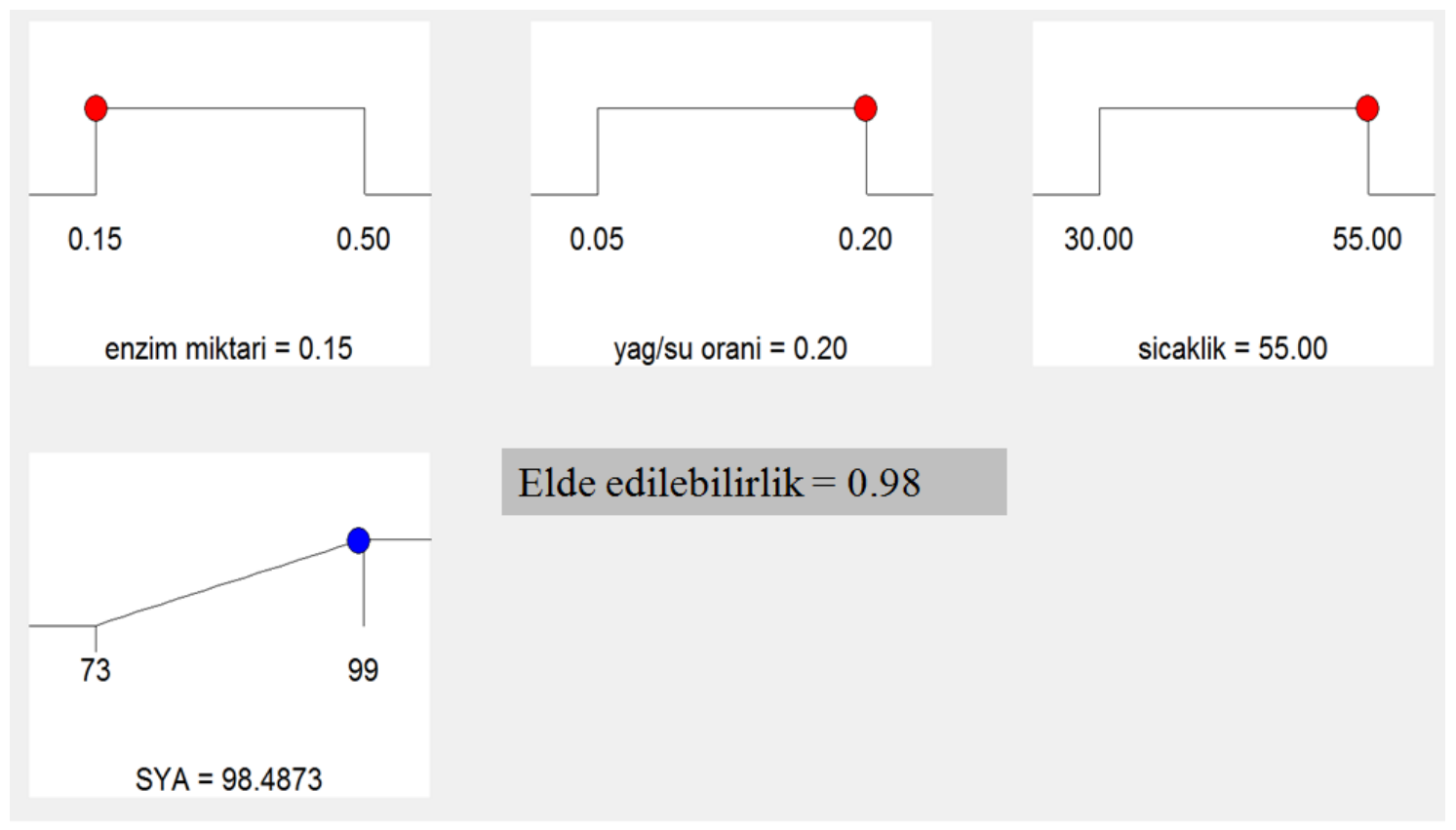

Şekil 7. Noopazyme katalizörlüğünde hidroliz tepkimesi için model optimizasyonu çalışması

Tasarlanan modelin ve deneysel sonuçların doğrulanması için en yüksek ve en düşük SYA dönüşümleri çalışılmıştır. Deneysel çalışmalar sonucunda en yüksek SYA dönüşümüne (\%99), enzim miktarı 0.32 (\%gr yağa göre), yağ/su oranı
0.13 (gr/gr) ve $63.52{ }^{\circ} \mathrm{C}$ sicaklıkta ulaşılmıştır. Aynı koşullarda modelin öngördüğü SYA dönüşümü \%98'dir. En düşük SYA dönüşümü (\%73) enzim miktarı ve yağ su oranı aynı kalırken $21.48{ }^{\circ} \mathrm{C}$ sıcaklıkta elde edilmiştir. Bu koşullarda 
Programın öngördüğü en düşük SYA dönüşümü \%74.17'dir.

Ayrıca, önerilen modelin Cook mesafesi ve DFFTIS ölçümleri ve her iki değer, önerilen modelin uygunluğu için 1 'den az olmalıdır. DFFTIS değeri önerilen bir istatistiksel regresyonda bir noktanın ne kadar etkili olduğunu göstermek için kullanılan teşhisdir (Nigiz, 2019). Elde edilen sonuçlara göre, verilen sınır değerlerde tepkime koşulları uygulandığında SYA dönüşüm sonuçlarının kontrol edilebilir olduğu kabul edilmektedir. Tablo 7'de deneysel ve modelin öngördüğü sonuçlarının Cook mesafesi ve DFFTIS ölçümleri görülmektedir.

Tablo 7 Deneysel sonuçları ve öngörülen değerlerin Cook mesafesi ve DFFTIS ölçümleri

\begin{tabular}{cccccc}
\hline $\begin{array}{c}\text { Deney } \\
\text { Numarası }\end{array}$ & $\begin{array}{c}\text { Deneysel } \\
\text { SYA }(\%)\end{array}$ & $\begin{array}{c}\text { Öngörülen } \\
\text { SYA }(\%)\end{array}$ & Artık & DFFITS & $\begin{array}{c}\text { Cook } \\
\text { Mesafesi }\end{array}$ \\
\hline 1 & 83.00 & 81.62 & 1.38 & 1.983 & 0.359 \\
2 & 87.00 & 85.39 & 1.61 & $* 2.41$ & 0.488 \\
3 & 81.00 & 81.82 & -0.82 & -1.107 & 0.128 \\
4 & 84.00 & 84.10 & -0.095 & -0.124 & 0.002 \\
5 & 97.00 & 96.78 & 0.22 & 0.238 & 0.009 \\
6 & 98.00 & 97.05 & 0.95 & 1.285 & 0.168 \\
7 & 97.00 & 98.49 & -1.49 & $*-2.17$ & 0.417 \\
8 & 96.00 & 97.26 & -1.26 & -1.776 & 0.299 \\
9 & 92.00 & 91.52 & 0.48 & 0.508 & 0.028 \\
10 & 93.00 & 93.66 & -0.66 & -0.694 & 0.052 \\
11 & 90.00 & 92.41 & -2.41 & $*-3.40$ & 0.702 \\
12 & 95.00 & 92.76 & 2.24 & $* 2.99$ & 0.605 \\
13 & 73.00 & 74.17 & -1.17 & -1.295 & 0.166 \\
14 & 99.00 & 98.00 & 1.00 & 1.087 & 0.121 \\
15 & 92.00 & 92.16 & -0.16 & -0.042 & 0.000 \\
16 & 94.00 & 92.16 & 1.84 & 0.504 & 0.025 \\
17 & 92.00 & 92.16 & -0.16 & -0.042 & 0.000 \\
18 & 92.00 & 92.16 & -0.16 & -0.042 & 0.000 \\
19 & 90.00 & 92.16 & -2.16 & -0.610 & 0.034 \\
20 & 93.00 & 92.16 & 0.84 & 0.218 & 0.005 \\
\hline
\end{tabular}

*Limit dış1

\subsection{Literatür ile karşılaştırma}

$\mathrm{Bu}$ çalışmada, literatürde ilk defa Chlorella protothecoides mikroalg yağının enzim katalizli hidrolizi prosesine etki eden parametrelerin istatiksel optimizasyonu yapılmıştır. Lipaz enzimleri varlığında farklı kaynaklardan elde edilen yağların 1lımlı proses koşullarında hidroliz edildiği ve ürün saflaştırma işlemlerinin kimyasal katalizörlü proseslere karşın çevreci olduğu bilinmektedir. Literatürde farklı lipazlar varlığında farklı hammadde kaynağı kullanılarak yapılan çalışmalar bulunmaktadır. Bu çalışma ile yenebilen 1. Nesil yağlara alternatif günümüzde 3. Nesil mikroalg yağlarının hammadde olarak kullanılabilirliği doğrulanmıştır. Mikroalg yağlarının kullanımı tarım arazilerine gerek duymadan yüksek kapasitelerde yetiştirilmeleri ve yüksek fotosentez kabiliyetleri açışından daha çevreci bir proses olma özelliği sunmaktadır. Tablo 8 'de literatürde yapılmış çalışmalardan bazı lipaz katalizli hidroliz tepkimeleri verilmektedir.

Optimizasyon sonucunda en yüksek verimle elde edilen alg yağı SYA için yağ asidi bileşimi belirlenmiştir. Elde edilen sonuçlar alg yă̆ının $\% 63$ oleik asit ve \%20 linoleik asit içerdiğini göstermiştir. Yağ asidi bileşimi Tablo 9'da verilmiştir. 
Tablo 8. Farklı yağ kaynaklarının lipaz katalizli hidroliz tepkime çalışmaları

\begin{tabular}{|c|c|c|c|c|c|}
\hline Yăg & $\begin{array}{l}\text { Lipaz ve miktarı } \\
\text { (yağa göre (gr)) }\end{array}$ & $\begin{array}{c}\text { Yağ/su } \\
\text { oranı } \\
(\mathbf{g} / g)\end{array}$ & $\begin{array}{c}\left.\text { Sicaklık( }{ }^{\circ} \mathrm{C}\right) \text { ve } \\
\text { zaman(saat) }\end{array}$ & $\begin{array}{c}\text { SYA } \\
\text { dönüşümü } \\
(\%)\end{array}$ & Kaynak \\
\hline Soya & Candida rugosa $\% 30$ & $2 / 1$ & 40 ve 5 & 88 & Ting vd., 2008 \\
\hline Atık ayçiçek & Candida rugosa $\% 5$ & $1 / 1$ & 30 ve 10 & 100 & Talukder vd, 2010a \\
\hline Soya & $\begin{array}{l}\text { Thermomyces } \\
\text { lanuginosus \%2.3 }\end{array}$ & $1 / 1$ & 60 ve 48 & 89 & Oliveira vd., 2011 \\
\hline Findik & Jatropha curcas L. $\% 10$ & $1 / 10$ & 40 ve 2 & 98 & Sousa vd., 2010 \\
\hline Palmiye macuaba & Lipozyme RM IM & $1 / 2$ & 30 ve 6 & 99 & Aguieiras vd., 2014 \\
\hline Sabun stok & Candida rugosa $\% 5$ & $1 / 5$ & 30 ve 24 & 92 & Watanebe vd., 2007 \\
\hline Palmiye & Candida rugosa $\% 1$ & $1 / 1$ & 30 ve 4 & 100 & Talukder vd, 2010b \\
\hline Mikroalg & Noopazyme \%15 & $1 / 5$ & 55 ve 24 & 96.5 & Bu çalışma \\
\hline
\end{tabular}

Tablo 9. Chlorella protothecoides mikroalg yağının yă̆ asidi bileşimi

\begin{tabular}{cc}
\hline Yağ asidi & \% Bileşim \\
\hline C16:0 Palmitik & 3 \\
C16:1Palmitoleik & 9 \\
C18:1 Oleik asit & 63 \\
C18:2 Linoleik asit & 20 \\
C18:3 $\alpha$ Linolenik asit & 5 \\
\hline
\end{tabular}

\subsection{Noopazyme lipazının tekrar kullanılabilirliği}

Elde edilen en yüksek SYA dönüşümüne (\%98) ulaşılan deneysel koşullarda katalizörün tekrar kullanılabilirliğinin araştırılması amacı ile aynı katalizör tepkimelerde tekrar kullanılmıştır. Her bir tepkime sonucunda lipazlar ortamdan ayrilip buzdolabında bir sonraki tepkimede kullanılmak üzere $+4^{\circ} \mathrm{C}$ de muhafaza edilmiştir. Ardışı kullanımı sonucunda lipazın aktivitesindeki değişim Şekil 8'de verilmiştir.

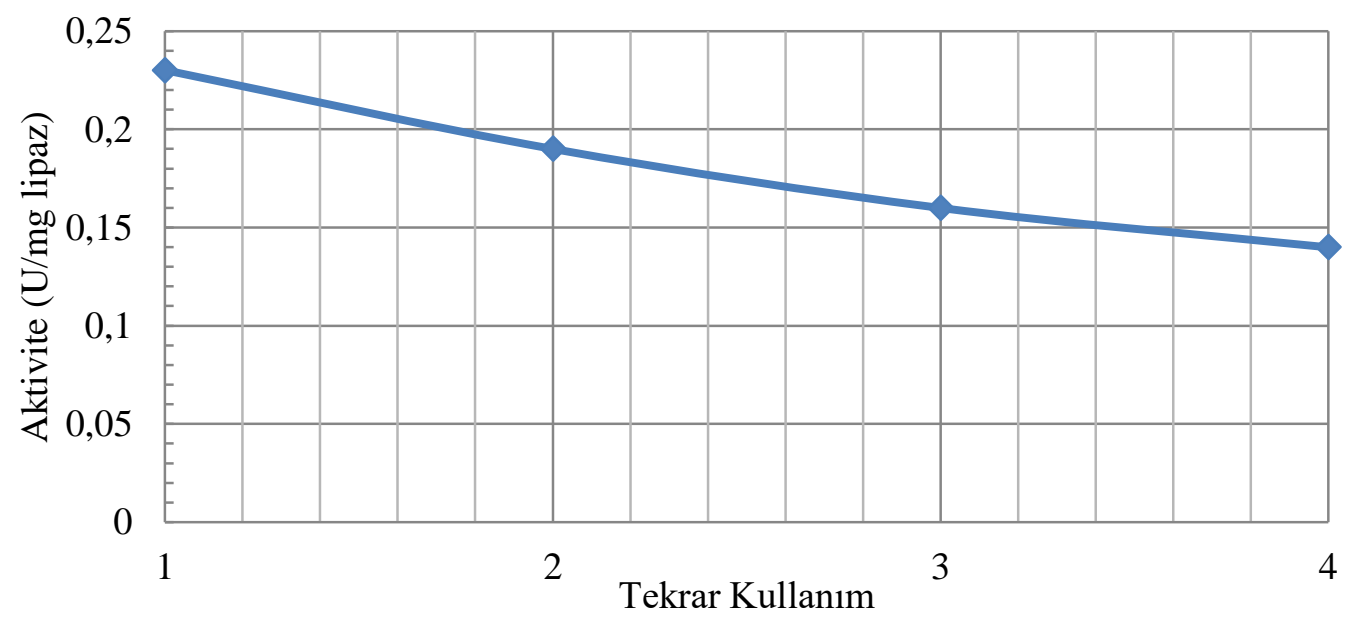

Şekil 8. Noopazyme lipazının tekrar kullanılması ile aktivitesinin değişimi

Şekil 8'den görüldüğü üzere Noopazyme enziminin hidroliz tepkimesinde 4 kez kullanımı sonucunda başlangıç aktivitesinin $(0.23 \mathrm{U} / \mathrm{mg}$ Lipaz) yaklaşık \%40'ını kaybettiği açıkça görülmektedir. Hidroliz tepkimeleri sonucunda lipaz ortamdan santrifüj ile ayrilarak n-hekzan ile yıkama işlemine tabi tutulmaktadır. Yıkamaayırma periyotları sonucunda lipazın tutuklanmış olduğu iyonik olmayan reçinenin tepkime ve yıkama ortamında çözündüğü ve lipazın ayrıldığg düşünülmektedir. Ayrıca lipazın tekrar eden uzun tepkime süreleri boyunca protein yapısının bozularak aktivitesinin düştüğü bilinmektedir. Lipazın aktif bölgelerinin çözücü tarafindan olumsuz etkilenerek aktivitesinin olumsuz yönde etkileneceği bilinmektedir. Noopazyme lipazının tekrar kullanılabilirliğini arttırabilecek daha dayanıklı destek maddelerine (polimer yapılı örneğin kitosan ve polivinilalkol vb.) tutuklanarak kullanılması önerilmektedir.

\section{Sonuçlar}

$\mathrm{Bu}$ çalışmada son yıllarda araştırmacıların ilgi odağı olan geleneksel (hayvansal, bitkisel) yağlara alternatif mikroalg yağının lipaz katalizörlügünde çevre dostu 1lımlı koşullarda gerçekleşen hidroliz prosesi ile birçok endüstride (kozmetik, petrol 
yağlama yağı vb.) hammadde olarak kullanılan serbest yă asitleri yüksek dönüşümle sentezlenmiştir. Lipaz katalizli hidroliz tepkimesine etki eden önemli parametrelerin (lipaz miktarı (\%gr yağa göre), sıcaklık, yağ/su (g/g)) ve bu parametrelerin birbirleri ile ilişkileri/etkileşimleri istatiksel olarak incelenmiştir.

Deneysel çalışmalar sonucunda aşağıdaki sonuçlar çıkarılmıştır;

Noopazyme lipazı katalizörlüğünde Chlorella protothecoides mikroalg yağının hidroliz tepkimesi için sıcaklık ve lipaz miktarının SYA dönüşümüne etkilerinin en önemli olduğu, bunun yanında yağ/su $(\mathrm{g} / \mathrm{g})$ oranının kisitlayıcı bir etkisinin olmadığ 1 belirlenmiştir.

İstatiksel çalışma ve optimizasyon sonucunda yüksek SYA dönüşümü (\%98), lipaz miktarı $\% 15$, yağ/su oran $1(\mathrm{~g} / \mathrm{g}) \quad 0.20$ ve sicaklık $55^{\circ} \mathrm{C}$ olduğu optimum koşullarda elde edilebileceği belirlenmiştir.

Lipazın bu tepkimelerde 4 tekrar kullanımı sonucunda aktivitesinde $\% 40$ oranında düşüş gözlenmiştir.

Hidroliz tepkimesi sonucunda serbest yağ asitleri başarılı bir şekilde sentezlenmiş aynı zamanda tepkime yan ürünü olan gliserol de elde edilmiştir. Serbest yağ asitleri ve gliserolün endüstride birçok kullanım alanı mevcuttur. Yapılan bu çalışma ile elde edilen sonuçlar, ileride yapılacak olan çalışmalar ve kurulması planlanan çevre dostu endüstriyel işletmeler için umut verici niteliktedir. Ayrica hammadde olarak mikroalglerin ve yağlarının, bitkisel ve hayvansal yağlara alternatif, birim zamanda ve alanda daha fazla üretilebilir ve ekonomik olmaları nedeni ile yakın gelecekte yaygın olarak kullanılabileceği öngörülmektedir.

\section{Kaynaklar}

Aguieiras, E. C. G., Oliveira, E. D., Castro, A. M., Langone, M. A. P. and Freire, D. M. G. (2014). Biodiesel production from Acrocomia aculeata acid oil by (enzyme/enzyme) hydroesterification process: use of vegetable lipase and fermented solid as low-cost biocatalysts. Fuel, 135, 315321. https://doi.org/10.1016/j.fuel.2014.06.069

Altın, N. (2017). Chlorella variabilis türü mikroalgin büyümesine ve yağ içeriğine etki eden parametrelerin belirlenmesi, Yüksek Lisans Tezi, Kocaeli Üniversitesi Fen Bilimleri Enstitüsü, Kocaeli.
Bahadi, M., Yusoff, M. F., Salimon, J. and Derawi, D. (2020). Optimization of response surface methodology by d- optimal design for alkaline hydrolysis of crude palm kernel oil. Sains Malaysiana, $\quad 49, \quad 29-41$. https://doi.org/10.17576/jsm-2020-4901-04

Castro, H. F., Mendes, A. A., Santos, J. C. and Aguiar, C. L. (2004). Modification of oils and fats by biotransformation. Química Nova, 27, 146-156. https://doi.org/10.1590/S010040422004000100025

Chen, W., Sun, S., Liang, S., Peng, L., Wang, Y. and Shen, M. (2014). Lipase-catalyzed hydrolysis of linseed oil: optimization using response surface methodology. Journal of Oleo Science, 64, 619628. https://doi.org/10.5650/jos.ess13189

Chu, B. S., Quek, S. Y. and Baharin, B. S. (2003). Optimization of enzymatic hydrolysis for concentration of vitamin $\mathrm{E}$ in palm fatty acid distillate. Food Chemistry, 80, 295-302. https://doi.org/10.1016/S0308-8146(02)00178-4

David, F., Sandra, P. and Vickers, A. K. (2005). Column selection for the analysis of fatty acids methyl esters. Application Agilent Technologies Incorporation.

Hasan, F., Shah, A. A. and Hameed, A. (2009). Methods for detection and characterization of lipases: a comprehensive review. Biotechnology Advances, 27 , 782-798. https://doi.org/10.1016/j.biotechadv.2009.06.00 1

Hung, C. S., Nguyen, C. H., Nguyen, M. L., Tran, P. T., Wang, F. M. and Guan, Y. L. (2018). Liquid lipase-catalyzed hydrolysis of gac oil for fatty acid production: Optimization using response surface methodology. Biotechnology Progress, 34 , 1129-1136. https://doi.org/10.1002/btpr.2714

Kumar, T., Kumar, S. and Kumar, S. (2003). Adsorption of resorcinol and catechol on granular activated carbon: equilibrium and kinetics. Pergamon Carbon, 41, 3015-3025. https://doi.org/10.1016/S0008-6223(03)00431-7

Maruyama, T., Nakajima, M., Ichikawa, S., Nabetani, H., Furusaki, S. and Seki, M. (2000). Oil-water interfacial activation of lipase for interesterification of triglycerideand fatty acid. Journal of American Oil Chemistry Society, 77, 1121-1127. https://doi.org/10.1007/s11746-000$0176-4$

Montgomery, C. D. (2012). Design and Analysis of Experiments (8th ed.). New York: John Wiley \& Sons. 
Murty, V. R., Bhat, J. and Muniswaran, P. K. A. (2002). Hydrolysis of oils by using immobilized lipase enzyme: a review. Biotechnology and Bioprocess Engineering, 7, 57-66. https://doi.org/10.1007/BF02935881

Neena, N. G. (1997). Application of lipase. Journal of American Oil Chemistry Society, 74, 621-634. https://doi.org/10.1007/s11746-997-0194-x

Nigiz, F. U. (2019). Synthesis of a novel graphenekaolin-alginate adsorbent or dye removal, and optimization of the adsorption by response surface methodology. Research on Chemical Intermediates, 45, 3739-3753. https://doi.org/10.1007/s11164-019-03818-z

Oliveira, E. D., Silva, P. R., Ramos, A. P., Aranda D. A. G. and Freire, D. M. G. (2011). Study of soybean oil hydrolysis catalyzed by Thermomyces lanuginosus lipase and its application to biodiesel production via hydroesterification. Enzyme Research, https:// doi.org/10.4061/2011/618692.

Özgen, M. (2013). Halofilik arkeal kaynakl lipaz üretim koşullarının optimizasyonu ve aktif lipazın saflaştırılması, Yüksek Lisans Tezi, Yıldız Teknik Üniversitesi Fen Bilimleri Enstitüsü, İstanbul.

Rooney, D. and Weatherley, L. R. (2001). The effect of reaction conditions upon lipase catalysed hydrolysis of high oleate sunflower oil in a stirred liquid-liquid reactor. Process Biochemistry, 36, 947-953. https://doi.org/10.1016/S0032-9592(01)00130-3

Russell, V. L. (2009). Response surface methods in using RSM. Journal of Statistical Software, 32, 1-17. https://doi.org/10.18637/jss.v032.i07

Sharma, A., Chaurasia, P. S. and Dalai, A. K. (2012). Enzymatic hydrolysis of cod liver oil for the fatty acids production. Catalysis Today, 207, 93-100. https://doi.org/10.1016/j.cattod.2012.05.006

Sharma, S., Gangal, S. and Rauf, A. (2009). Lipase mediated hydrolysis of Mimusops elengi Parkinsonia aculeata and seed oils for determining the positional distribution of fatty acids. Industrial Crops and Products, 30, 325328.

https://doi.org/10.1016/j.indcrop.2009.04.004

Shrivastsvs, A., Sandagar, P., Baja, I. and Singhal, R. (2008). Media optimization for the production of U-linolenic acid by Cunninghamella Echinulata var. elegans MTCC 522 using response surface methodology. International Journal of Food Engineering, $4, \quad 1-32$. https://doi.org/10.2202/1556-3758.1178
Stoytcheva, M., Montero, G., Zlatev, R., León, J. A. and Gochev, V. (2012). Analytical methods for lipases activity determination: a review. Current Analytical Chemistry, 8, 400-407. https://doi.org/10.2174/157341112801264879

Sousa, J. S., Cavalcanti-Oliveira, E. D., Aranda, D. A. G. and Freire, D. M. G. (2010). Application of lipase from the physic nut (Jatropha curcas L.) to a new hydrid (enzyme/chemical) hydroesterification process for biodiesel production. Journal of Moleculaer Catalysis B: Enzymatic, 65, 133-137. https://doi.org/10.1016/j.molcatb.2010.01.003

Talukder, M. M. R., Wu, J. C., Fen, N. M. and Melissa, Y. L. S. (2010a). Two step lipase catalysis for production of biodiesel. Biochemical Engineering Journal, 49, 207-212. https://doi.org/10.1016/j.bej.2009.12.015

Talukder, M. M. R, Wu J. C. and Chua, L. P. L. (2010b). Conversion of waste cooking oil to biodiesel via enzymatic hydrolysis followed by chemical esterification. Energy Fuel, 24, 2016-2019. https://doi.org/10.1021/ef9011824

Ting, W. J, Huang, C. M., Nair G. R. and Wu W. T. (2008). An enzymatic/acid-catalyzed hybrid process for biodiesel production from soybean oil. Journal of the Chinese Institute of Chemical Engineers, 39, 203-210. https://doi.org/10.1016/j.jcice.2008.01.004

Watanabe, Y., Nagao, T., Nishida, Y., Takagi, Y. and Shimada, Y. (2007). Enzymatic production of fatty acid methyl esters by hydrolysis of acid oil followed by esterification. Journal of American Oil Chemists' Society, 84, 1015-1021. https://doi.org/10.1007/s11746-007-1143-4

Xin, C., Wei, D. and Liu D. (2008). Effect of several factors on soluble lipase mediated biodiesel preparation in the biphasic aqueous-oil systems. Journal of Microbiology and Biotechnology, 24, 2097-2102. https://doi.org/ 10.1007/s11274-0089714-6

Yadav, G. D. and Borkar, I. V. (2009). Synthesis of nbutyl acetamide over immobilized lipase. Journal of Chemical Technology and Biotechnology, $84, \quad 420-426$. https://doi.org/10.1002/jctb.2056

Yadav, G. D. and Devi, K. M. (2004). Kinetics of Hydrolysis of Tetrahydrofurfuryl Butyrate in a Three Phase System Containing Immobilized Lipase from Candida Antarctica. Biochemical Engineering Journal, 17, 57-63. https://doi.org/10.1016/S1369-703X(03)001256

Yadav, G. D., Sajgure, A. D. and Dhoot, S. B. (2008). Insight into microwave irradiation andenzyme 
catalysis in enantioselective resolution of RSmethyl mandelate. Journal of Chemical Technology and Biotechnology, 83, 145-1153. https://doi.org/10.1002/jctb.1975

Yan, J., Liu, S., Hu, J., Gui, X., Wang, G. and Yan, Y. (2011). Enzymatic enrichment of polyunsaturated fatty acids using novel lipase preparations modified by combination of immobilization and fish oil treatment. Bioresource Technology, 102, 7154-7158. https://doi.org/10.1016/j.biortech.2011.04.065

Yuan, X., Liu, J., Zeng, G., Shi, J., Tong, J. and Huang, G. (2008). Optimization of conversion of waste rapeseed oil with high FFA to biodiesel using response surface methodology. Renewable Energy, 33, 1678-1684.

Zenevicz, M. P., Jacques, A., Furigo, A., Oliveira, J. V. and Oliveira, D. (2016). Enzymatic hydrolysis of soybean and waste cooking oils under ultrasound system. Industrial Crops and Products, 80, 235241.

https://doi.org/10.1016/j.indcrop.2015.11.031 